also phylogenetically divided into two sub-generaone containing the glossy and the other the mat petalled species.

Marsden-Jones and Turrill are collaborating in a genetical study of this genus, and last year they published a preliminary account of their results with the two common buttercups, Ranunculus acris and $R$. bulbosus (Jour. of Genetics, 21, abstract in Nature, 124, p. 928). One of the most interesting points connected with these species is the occurrence of plants functionally only female. Reference to these was made in the correspondence columns of NATURE last year (123, pp. 568, 798, and 911).

A Japanese botanist, M. Kumazawa, has this year published the results of his morphological and anatomical study of the species of Ranunculus occurring in his own country (Jour. Faculty of Science, Univ. Tokyo, Botany 2, pt. 3). The island empire of Japan is sometimes regarded as the eastern counterpart of the British kingdom, and in keeping with this it so happens that the number of species (sixteen) found there is about equal to the number usually recognised in Britain. Furthermore, as in the British flora, the only species that have not yellow and glossy petals are white water buttercups.

Two endemic species present interesting vegetative features. Ranunculus Zuccarini has root tubers suggestive of those of the Lesser Celandine ( $R$. Ficaria). Ranunculus flagellifolius has filiform leaves monocotyledonous in appearance. Evidence is brought forward to show that these foliar organs have evolved through the transformation of the whole of an ordinary leaf and are not merely modified leaf stalks (phyllodes).

The main part of the paper is taken up with vascular anatomy. Interesting points in connexion with the endodermis are described. There is a marked tendency in the stem to closed bundles of the monocotyledonous type.

From the morphological and anatomical point of view Ranunculus sceleratus, a widely distributed species and fairly common in Britain, is regarded probably as one of the most primitive members of the genus.

\section{Autumn-sown Cereals.}

THE choice of a good variety of cereal may make a difference of more than twenty per cent in a farmer's returns, and yet the crop will cost him no more to grow. For this reason the National Institute of Agricultural Botany, Cambridge, has issued a number of recommendations, based on careful trials at a number of stations, as to varieties of cereals suitable for autumn sowing. These do not necessarily apply to the north of England, but may be accepted with confidence in other districts.

The reaction of different varieties of wheat to diseases such as foot-rot or whiteheads is as yet far from complete, but there is no reason to believe that any one variety is markedly more resistant or susceptible to them than another. As regards winter hardiness, it should be borne in mind that other factors besides frost resistance are important in England, and that on the whole, Scandinavian and Dutch wheats are less adapted to our conditions than such a variety as Squarehead's Master. The value of change of seed is still a vexed question, but there seems no evidence (given equal purity and germination) that foreign-grown seed is preferable to stocks of the same variety grown in England.

Wilhelmina or Victor are the most trustworthy highyielding varieties on soils in good condition; Yeoman or Yeoman II possess unique bread-making quality and are the varieties to grow on the richest soils or under intensive manuring; Little Joss should be chosen for the lighter wheat soils, particularly in Norfolk, or where fertility is low ; Iron III, though less trustworthy than Wilhelmina and apt to develop rust, like Weibull's Standard, finds a place on heavy soils. Rivett, or Blue Cone, probably outyields all other varieties on heavy soils in the south of England, and Squarehead's Master stands by itself in its adaptability to all sorts of conditions and the regularity with which it gives a certain crop.

Grey Winter is the only really trustworthy variety of oats, but its weak straw is a serious disadvantage. If strength of straw is an essential point, black-grained Bountiful is suggested. There is no winter-hardy white oat on the market. As regards barley, the ordinary six-row winter variety gives a satisfactory crop, but the grain is not of malting quality. However, although none of the malting barleys are winterhardy, Plumage Archer and Spratt Archer can usually be grown successfully, if exposed situations and badly drained soil are avoided, and when autumn-sown, outyield similar spring-sown crops. Anyone wishing for fuller particulars is advised to write to the National Institute of Agricultural Botany at Cambridge.

\section{University and Educational Intelligence.}

BIRMINGHAM.-The celebration of the jubilee of Mason College and the thirtieth anniversary of the granting of a charter to the University commenced on Oct. 13. The Chancellor, the Viscount Cecil of Chelwood, in the course of his address, referred to the foundation in 1880, by Sir Josiah Mason, of Mason College as a college of science and technical knowledge for Birmingham, at a cost of $£ 200,000$. The College became the University in 1900, and the first principal was Sir Oliver Lodge, who was present at the celebra. tions. The honorary degree of doctor of laws was conferred on the following, among others: Sir Henry Hadow, Sir William Hardy, Sir Thomas Lewis, and Dr. F. E. Smith.

Cambridge.-At Trinity College, J. W. Brunyate, L. H. Gray, and R. E. A. C. Paley have been elected to fellowships. At Corpus Christi College, Dr. G. S. Carter, formerly lecturer in zoology in the University of Glasgow, has been elected to a fellowship.

The John Winbolt Prize has been awarded to $\mathbf{S}$. Steele, of Christ's College, for a dissertation on "Chemical Changes in Fuel-air Mixtures in an Internal Combustion Engine during Compression".

London.- Two courses of advanced lectures have been arranged in the Faculty of Engineering at King's College. Mr. T. G. Rose is giving three lectures on "Management", on Tuesdays, beginning Oct. 21 ; and Col. C. H. Bressey, Chief Engineer, Roads Department, Ministry of Transport, will deliver three lectures on "Modern Road Construction", on Tuesdays, beginning Nov. 11. Particulars can be obtained from the College.

MANChester.-The Council has accepted with regret the resignation of Prof. O. T. Jones, who has held the chair of geology and the directorship of the Geological Laboratories since 1919. Prof. Jones has been elected to the Woodwardian chair of geology in the University of Cambridge, and will vacate his Manchester appointment in December. The Council has also accepted the resignations of Dr. John Walton, senior lecturer in botany, who has been elected to the Regius chair of botany in the University of Glasgow, and of Mr. L. J. F. Brimble, lecturer in botany.

No. 3181, VoL. 126] 